\title{
OBEZITATEA ŞI DISLIPIDEMIILE LA COPILUL CU HEPATITĂ CRONICĂ
}

\author{
Alice N. Azoicăi, Bogdan A. Stana, Paula Popovici, Ileana K. Ioniuc, \\ Monica M. Alexoae, Irina Crişcov, Alina M. Murgu, Evelina Moraru \\ Clinica II Pediatrie, Spitalul Clinic de Urgență pentru Copii „Sf. Maria“, \\ Universitatea de Medicină şi Farmacie „, Gr. T. Popa “, Iaşi
}

\begin{abstract}
REZUMAT
Asocierea hepatitelor cronice cu diverse tipuri de dislipidemii este o realitate nu numai pentru pacientul obez, la care ne aşteptăm să găsim hipercolesterolemii sau/şi hipertrigliceridemii, dar şi pentru copilul normoponderal. Cauzele acestei asocieri sunt multiple, însă trebuie să avem în vedere, în primul rând, predispoziția familială şi transmiterea genetică a unor forme de dislipidemii. În acelaşi timp, unele dislipidemii sunt secundare hepatopatiilor cronice, astfel că se formează un cerc vicios în care tratamentul de primă intenție a dezechilibrelor metabolice este de mare importanță în succesul terapiei antivirale.
\end{abstract}

Cuvinte cheie: hepatită, dislipidemie, obezitate, copil

\section{INTRODUCERE}

Prevalența dislipidemiei la bolnavii cu hepatită cronică sub terapie antivirală poate fi pusă pe seama efectului exercitat de Interferon care, asemănător antiretroviralelor, produce scăderea limfocitelor CD4 pozitive, dar şi a IMC, a caracteristicilor individuale metabolice ale indivizilor, a coexistenței sau preexistenței unor stări patologice. $(1,2)$ Majoritatea studiilor recunosc inhibitorii proteazici ca fatori de risc în dezvoltarea dislipidemiilor, pe lângă alte mecanisme, cum ar fi inhibarea lipoproteinlipazelor, inducerea rezistenței la insulină sau tulburarea homeostaziei lipogeneză versus lipoliză cauzate de infecția virală propriu-zisă. (3) De asemenea, există dovezi care susțin efectul de stimulare a lipodistrofiei şi a redistribuirii țesutului adipos pe care îl au inhibitorii de revers-transcriptază nonnucleotidici la pacienții naivi la inhibitori de protează (3-5). Având în vedere faptul că atât tratamentul antiretroviral, cât şi cel antiviral al hepatitelor cronice implica un timp îndelungat, aceste efecte adverse trebuie monitorizate atent, putând constitui cauze serioase ale scăderii complianței la terapie, de întrerupere a tratamentului sau de reconsiderare a opțiunilor terapeutice. $(6,7)$

\section{MATERIAL ŞI METODE}

Lotul de studiu a cuprins 166 de pacienți (copii şi adolescenți) cu hepatită cronică, aflați în evidența Clinicii II Pediatrie a Spitalului Clinic de Urgență pentru Copii „Sfânta Maria“ din Iaşi. S-au luat în calcul IMC, valorile colesterolului şi trigliceridelor, precum şi status-ul terapeutic al pacienților, urmărindu-se stabilirea unor corelații între excesul ponderal sau obezitatea şi dislipidemiile (hipercolesterolemie, hipertrigliceridemie sau dislipidemie mixtă).

\section{REZULTATE}

În cazul obezității la pacienții cu hepatită cronică este remarcată o prezență semnificativă a dislipidemiilor $(68,7 \%)$, aspect demonstrat de valoare mare a statisticii Chi-pătrat $\chi^{2}=9,25, p=0,0023$ ).

Analiza corelațională demonstrează prezența unei corelații semnificative între obezitate şi prezența dislipidemiilor $(r=0,71, p=0,0009,95 \% \mathrm{CI})$. Aceste rezultate relevă importanța clară pentru aprofundarea terenului dismetabolic ca şi factor de risc şi de evaluare prognostică, precum şi a răspunsului la terapie a acestor indivizi. 


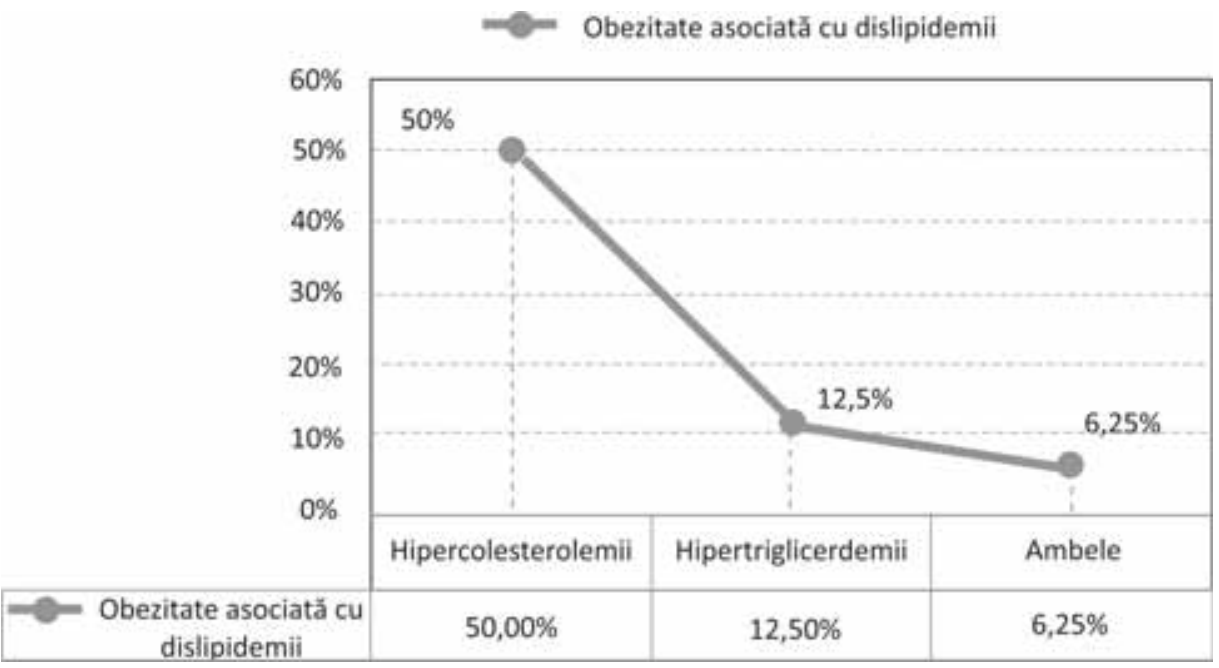

FIGURA 1. Asocierea obezității cu dislipidemiile

TABELUL 1. Parametrii estimați în testarea asocierii obezității cu prezența dislipidemiilor

\begin{tabular}{|l|c|c|}
\hline & Chi-pătrat $\chi^{2}$ & $\begin{array}{c}\mathbf{p} \\
\text { 95\% interval de } \\
\text { incredere }\end{array}$ \\
\hline Pearson Chi-pătrat $-\chi^{2}$ & 11,05 & 0,0008886 \\
\hline Yates & 9,25 & 0,0023537 \\
\hline $\begin{array}{l}\text { Coeficient de corelație } \\
\text { (Spearman Rank R) }\end{array}$ & 0,713 & 0,0009211 \\
\hline
\end{tabular}

TABELUL 2. Estimarea parametrilor de şansă şi risc în apariția dislipidemiilor datorate obezității

\begin{tabular}{|l|c|c|c|}
\hline & Valoare & \multicolumn{2}{|c|}{$95 \%$ Interval de confidență } \\
\cline { 3 - 4 } & estimată & Minim & Maxim \\
\hline PARAMETRII de șansă & & & \\
\hline Raport de șansă (OR) & 5,66 & 1,68 & 20,06 \\
\hline PARAMETRII de risc & & & \\
\hline Raport de risc (RR) & 2,46 & 1,62 & 3,73 \\
\hline
\end{tabular}

Evaluarea raportului de şansă în apariția dislipidemiilor demonstrează prezența unui risc retrospectiv de 5,66 ori mai mare în rândul pacienților cu obezitate. Pe baza rezultatelor din lotul analizat se poate estima prospectiv un risc pentru dislipidemii de 2,46, raportul de risc fiind de $\mathrm{RR}=2,46$.

Frecvența relativă a obezității a remarcat o creştere semnificativă în primele 60 de luni de la diagnostic, ajungând de la 4,18\% la momentul luării în evidență la 15,38\% după 48 de luni de la începerea tratamentului.

O abordare calitativă a influenței tratamentului asupra obezității copiilor a urmărit evoluția frecvenței cazurilor cu obezitate în dinamică. Rezultatele demonstrează asocierea semnificativă între tratament şi prezența obezității, aspect evidențiat atât de valoarea mare a coeficientului de corelaţie

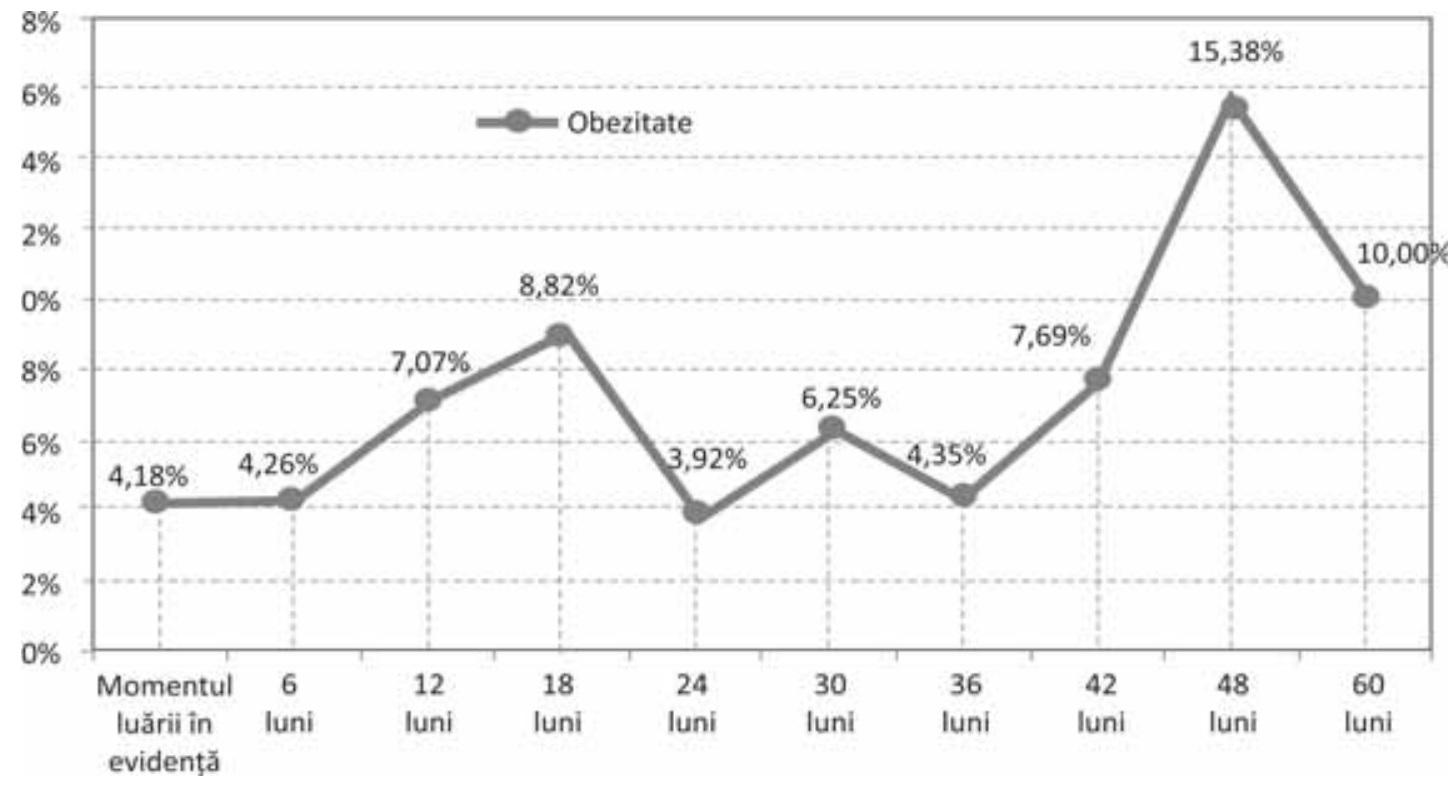

FIGURE 2. Frecvența obezității copiilor în dinamică 


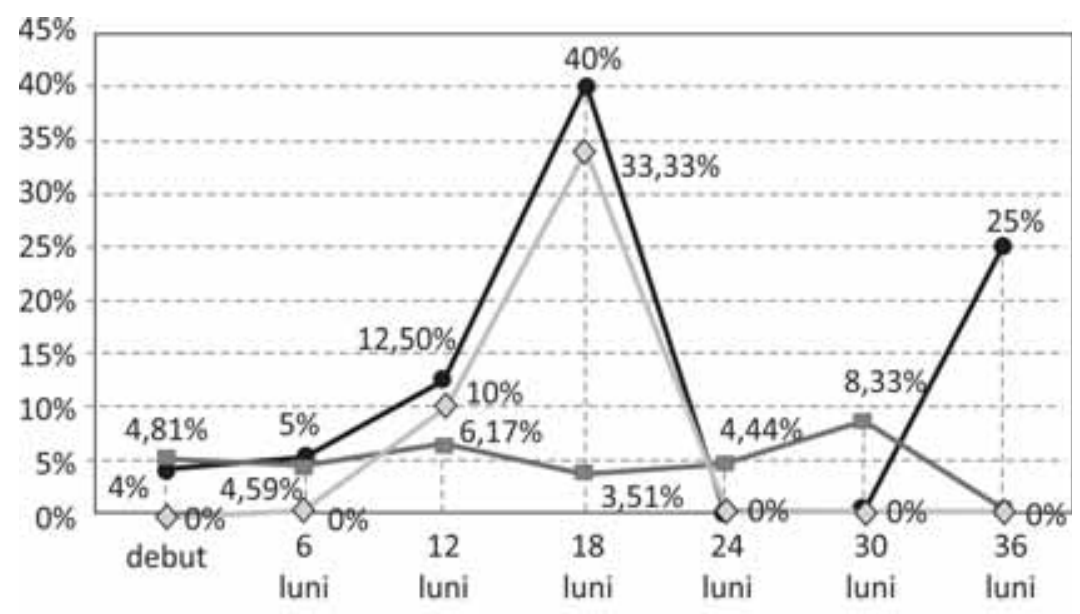

FIGURA 3. Frecvența obezității copiilor în dinamică în funcție de tratament

$(\mathrm{r}=0,642, \mathrm{p}=0,0340,95 \% \mathrm{CI})$, cât şi de valoare statisticii Chi-pătrat (M-L $\left.\chi^{2}=18,9, p=0,025,95 \% \mathrm{CI}\right)$. Frecvențele relative au fost calculate raportând la numărul cazurilor ce au putut fi evaluate la fiecare moment (număr total de cazuri corespunzător momentului).

TABELUL 4. Parametrii estimați în testarea asocierii tratamentului antiviral vs. obezitate

\begin{tabular}{|l|c|c|}
\hline$(\mathrm{df}=9)$ & $\begin{array}{c}\text { Chi-pătrat } \\
\chi^{2}\end{array}$ & $\begin{array}{c}\mathbf{p} \\
\text { 95\% interval de } \\
\text { incredere }\end{array}$ \\
\hline Pearson Chi-pătrat $-\chi^{\mathbf{2}}$ & 18.98101 & 0,02536 \\
\hline M-L corrected & 13.95425 & 0,012398 \\
\hline $\begin{array}{l}\text { Coeficient de corelație } \\
\text { (Spearman Rank R) }\end{array}$ & 0.6423218 & 0,034079 \\
\hline
\end{tabular}

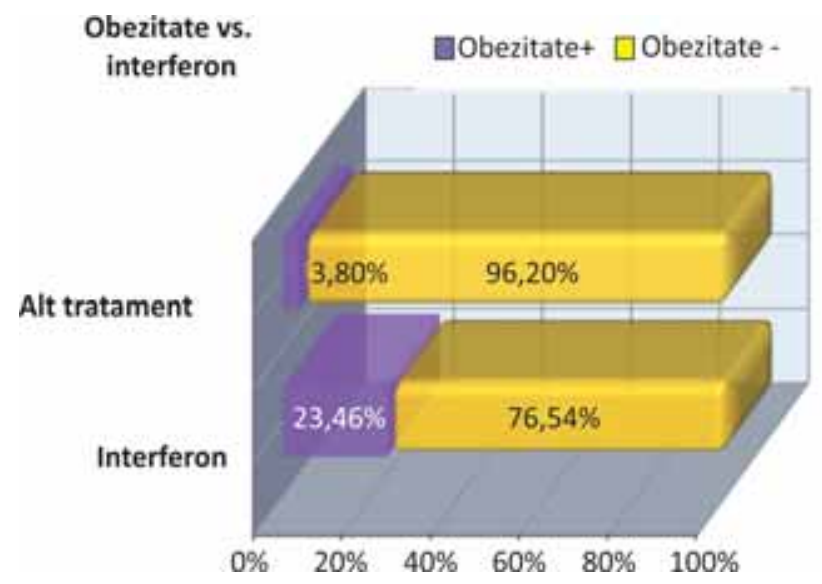

FIGURA 4. Asocierea obezității în tratamentul cu interferon

În cazul tratamentului cu interferon la pacienții cu hepatită cronică este remarcată o prezență semnificativă a cazurilor cu obezitate $(23,46 \%)$, comparativ cu alte terapii, aspect demonstrat de valoarea mare a statisticii Chi-pătrat $\chi^{2}=20,05, p=0,0000076$ ).
Deşi în literatură este demonstrat efectul invers, de pierdere ponderală, sub terapia cu Interferon, rezultatele obținute ar putea fi puse pe seama reluării alimentației hipercalorice şi hiperproteice după finalizarea terapiei. $(8,9)$ De asemenea, prudența privind scăderea în greutate, precum şi preexistența unui exces ponderal anterior inițierii tratamentului ar putea explica rezultatele studiului. Aşadar, scăderea ponderală sub IFN creşte riscul dezvoltării obezităţii după finalizarea terapiei (10).

\section{CONCLUZII}

Rezultatele studiului sugerează necesitatea unei investigații reale a dislipidemiilor la pacienții cu hepatită cronică, iniţial şi în timpul terapiei, pentru adaptarea sau suplimentarea tratamentului. $\mathrm{Nu}$ se poate aprecia ponderea efectivă a diagnosticului de hepatită cronică asupra creşterii IMC, având în vedere coexistența unor trăsături fenotipice, genotipice şi/sau particularităților de dietă.

În studiul nostru s-a remarcat o evoluție favorabilă a obezității, cu scăderea curbei ponderale şi a indicelui de masă corporală la unii pacienți care au primit tratament antiviral cu Interferon alfa, în unele cazuri scăderea în greutate corelându-se şi cu scăderea gradului de steatoză hepatică decelată ecografic.

Statinele şi fibrații ar trebui administrate cu reticență (mai ales la pacientul pediatric), având în vedere efectul musculotoxic, ştiut fiind faptul că infecția hepatitică cronică se asociază frecvent cu manifestări extrahepatice de tip mialgii, miozite sau rabdomioliză. Aşadar, se impune stabilirea unui echilibru între risc şi beneficiu în cazul categoriilor speciale de pacienți, inclusiv la copil, unde au fost descrise cazuri de boală coronariană datorată dislipidemiei. 
După cum nu există ghiduri pentru tratarea dislipidemiei în infecția HIV sau în cea hepatitică, se impune respectarea recomandărilor internaționale în ceea ce priveşte managementul hipertrigliceride- miei sau hipercolesterolemiei (dietă şi medicație), dar şi efectuarea de studii care să permită formularea unor direcții clare în abordarea acestor pacienți. 